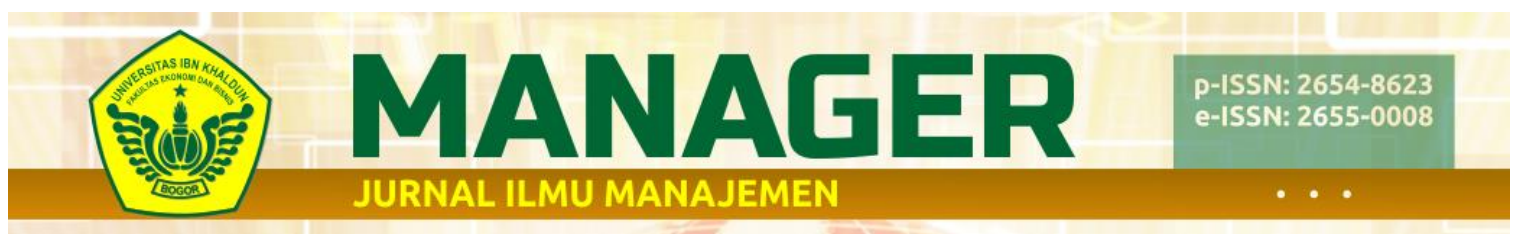

Vol. 2, No. 1, Maret 2019, Hal. 26 - 38

http://ejournal.uikabogor.ac.id/index.php/Manager/index

\title{
Perputaran Piutang Dan Perputaran Persediaan Terhadap Return On Invesment (Roi)
}

\author{
Dara Ratna Wulan, Supramono ,Titing Suharti \\ Fakultas Ekonomi Dan Bisnis Universitas Ibn Khaldun Bogor,Indonesia \\ Dara@gmail.com, supramonouika@gmail.com,titing@gmail.com
}

\begin{abstract}
ABSTRAK
Analisis Laporan Keuangan merupakan Analisis mengenai kondisi keuangan suatu perusahaan yang melibatkan neraca dan laba rugi dan pastinya untuk memperoleh keuntungan. Dengan itu perlu juga adanya suatu rasio-rasio keuangan untuk pengukuran pada kinerja suatu perusahaan misalnya tentang rasio Return On Invesment (ROI) yang mana dengan rasio ini kita bisa mengetahui suatu keuntungan perusahaan dengan menggunakan suatu investasi atau menanamkan modalnya.

Adapun tujuan penelitian ini bermaksud untuk (1) mengetahui pengaruh perputaran piutang terhadap return on invesment pada perusahaan sektor properti yang terdaftar di Bursa Efek Indonesia (2) mengetahui pengaruh perputaran persediaan terhadap return on invesment pada perusahaan sektor properti yang terdaftar di Bursa Efek Indonesia dengan periode yang digunakan pada penelitian ini adalah dari 2010-2017.

Adapun populasi dalam penelitian ini yaitu perusahaan manufaktur Sub sektor properti yang terdaftar di Bursa Efek Indonesia dengan menggunakan sampel metode simple random sampling jumlah sampel sebanyak 3 perusahaan.

Berdasarkan hasil penelitian ini menunjukkan bahwa adanya (1) Perputaran Piutang secara parsial tidak terdapat pengaruh yang signifikan terhadap return on invesment, dengan nilai signifikan sebesar 0,867 $>0,05$ sedangkan pada nilai $t$ hitung $0,170<2,074$ t tabel (2) Perputaran Persediaan secara parsial tidak terdapat pengaruh yang signifikan terhadap return on invesment, dengan nilai signifikan sebesar 0,195 > 0,05 sedangkan pada nilai t hitung 1,335 2,074 t tabel (3) Perputaran Piutang dan Perputaran Persediaan secara simultan pun tidak terdapat

pengaruh yang signifikan terhadap Return On Invesment, yang mana nilai signifikannya sebesar 0,438 $>0,05$ sedangkan pada nilai $\mathrm{f}$ hitung 0,858 $<3,47 \mathrm{f}$ tabel.
\end{abstract}

Kata Kunci : Perputaran Piutang, Perputaran Persediaan, Return On Invesment (ROI). 


\section{Pendahuluan}

\section{Latar Belakang}

Perkembangan suatu bisnis usaha pada perusahaan yang kini semakin pesat harus terus bisa melakukan penerapan yang baik guna dalam suatu strategi karena banyak persaingan-persaingan dalam dunia bisnis ini yang sangat pesat, demi adanya suatu kelancaran pada perusahaan yang mana persaingan semakin pesat maka untuk itu perusahaan harus bisa mengoptimalkan suatu kinerja dengan baik supaya tingat keberhasilannya akan terus berkembang.

Keuntungan suatu bisnis
itu pastinya tujuan dari
perusahaan, dana yang bisa
digunakan untuk modal
perusahaan juga bisa dengan
adanya pemanfaatan dari suatu
investasi, maka nya harus bisa
mengoptimalkan secara efektif dan
efesien supaya terus adanya
peningkatan modal investasi
keuntungan pada suatu penjualan.
Penjualan yang dikelola
dengan menggunakan
alternatif kebijakan kredit yang
ditawarkan kepada pelanggan itu

sendiri, selain pelanggan itu merasa puas dengan suatu pembelian yang dikelola yang diinginkannya bisa juga memperoleh secara kredit, adanya kredit dalam perusahaan maka akan menghasilkan tagihan (piutang)

Piutang dalam suatu elemen berkaitan dengan adanya suatu persediaan yang saling berhubungan, karena perusahaan tidak akan melakukan aktivitas penjualannya kalau tidak ada persediaan seperti dari bahanbahan yang di butuhkan lainnya. Itulah adanya kaitan antara Persediaan dengan Piutang yang mana bisa digambarkan seperti Kas $\rightarrow$ Persediaan $\rightarrow$ Piutang $\rightarrow$ Kas.

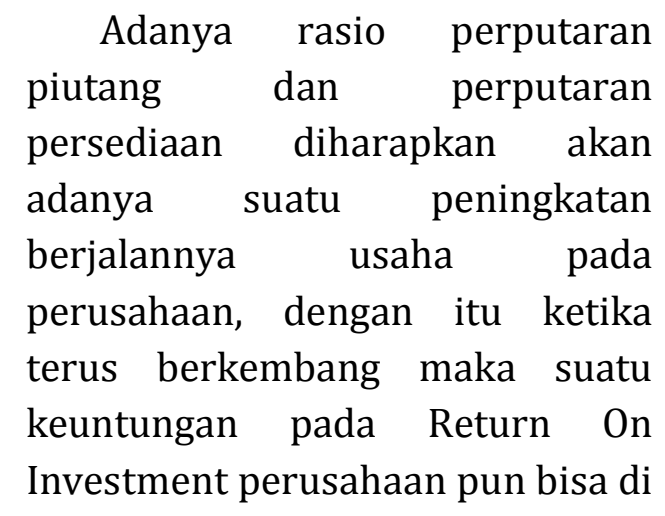


dapatkan untuk menutup investasi yang dikeluarkan pada suatu aktiva, karena jika keuntungan yang rendah maka ROI juga tidak akan meningkat sehingga menyebabkan akan tidak mampu menarik pemodal kembali dalam suatu investasi tersebut. Berdasarkan uraian sesuai latar belakang tersebut, penulis tertarik melakukan penelitian dengan memilih judul skripsi yaitu "Pengaruh Perputaran Piutang dan Perputaran Persediaan Terhadap Return On Investment (ROI) Pada Perusahaan Manufaktur Sub Sektor Properti Yang Terdaftar Di Bursa Efek Indonesia (BEI) (Studi kasus pada PT. Alam Sutera Reality Tbk, PT. Bekasi Asri Pemula Tbk, PT. Bumi Citra Permai Tbk Periode 2011-2017)".

\section{Rumusan Masalah}

Berdasarkan permasalahan diatas, dalam penelitian ini dapat dirumuskan sebagai berikut:

1. Apakah terdapat pengaruh perputaran piutang terhadap Return on Investment (ROI)?

2. Apakah terdapat pengaruh perputaran persediaan terhadap Return on Investment (ROI)?

\section{Metode Penelitian}

\section{Jenis Penelitian}

Jenis yang digunakan dalam penelitian ini adalah dengan menggunakan suatu data
3. Apakah terdapat pengaruh perputaran piutang dan perputaran persediaan secara bersama-sama terhadap Return on Investment (ROI)?

\section{Tujuan Penelitian}

Adapun tujuan penelitian ini sebagai berikut :

1. Untuk mengetahui pengaruh perputaran piutang terhadap Return on Investment (ROI) PT. Alam Sutera Reality Tbk, PT. Bekasi Asri Pemula Tbk, PT. Bumi Citra Permai Tbk selama Periode 2011-2017?

2. Untuk mengetahui pengaruh perputaran piutang dan perputaran persediaan terhadap Return on Investment (ROI) PT. Alam Sutera Reality Tbk, PT. Bekasi Asri Pemula Tbk, PT. Bumi Citra Permai Tbk selama Periode 20112017?

3. Untuk mengetahui pengaruh perputaran piutang dan perputaran persediaan terhadap Return on Investment (ROI) PT. Alam Sutera Reality Tbk, PT. Bekasi Asri Pemula Tbk, PT. Bumi Citra Permai Tbk selama Periode 20112017?

kuantitatif adalah penelitian yang menggunakan angka (numerical) dari hasil observasi dengan maksud untuk menjelaskan 
fenomena dari observasi, berupa data laporan keuangan tahunan yang diambil selama periode 2010 sampai 2017 Pada Perusahaan Manufaktur Sub Sektor Properti Yang Terdaftar Di Bursa Efek Indonesia (BEI) (Studi kasus pada PT. Alam Sutera Reality Tbk, PT. Bekasi Asri Pemula Tbk, PT. Bumi Citra Permai Tbk.

\section{Populasi dan Teknik Pengambilan Sampel}

Adapun populasi dalam penelitian ini adalah perusahaan manufaktur Sub sektor properti yang terdaftar di Bursa Efek Indonesia (BEI).

Dan adapun teknik pengambilan sampel dalam penelitian ini adalah yang diambil dari perusahaan manufaktur sub sektor properti yang terdaftar di Bursa Efek Indonesia (BEI).

Adapun sampel dalam penelitian ini adalah:

1. ASRI (PT. Alam Sutera Reality Tbk)

2. BAPA (PT. Bekasi Asri Pemula Tbk)

3. BCIP (PT. Bumi Citra Permai Tbk).

\section{Teknik Analisis Data}

1. Studi Kepustakaan

Merupakan suatu bentuk penelitian untuk memperoleh informasi dan data yang dibutuhkan, yang akan mendukung pada hasil penelitian yang berkaitan dengan acuan sumber buku-buku yang akan membahas masalah yang diteliti.

2. Studi Lapangan

Data yang dikumpulkan adalah data sekunder laporan keuangan yang tediri dari neraca dan laporan laba rugi pada Perusahaan Manufaktur Sub Sektor Properti Yang Terdaftar Di Bursa Efek Indonesia (BEI) (Studi kasus pada PT. Alam Sutera Reality Tbk, PT. Bekasi Asri Pemula Tbk, PT. Bumi Citra Permai Tbk Periode 20112017.

\section{Tinjauan Pustaka}

\subsubsection{Pengertian Persediaan}

Menurut Agus Sartono dalam bukunya yang berjudul Manajemen Keuangan Teori dan Aplikasi (2015:443) menjelaskan bahwa persediaan pada umumnya "Merupakan salah satu jenis aktiva lancar yang jumlahnya cukup besar dalam suatu perusahaan".

Karena persediaan merupakan faktor penting dalam menentukan kelancaran operasi perusahaan. Pengertian persediaan mencakup pengertian yang sangat luas, mencakup persediaan yang terdapat dalam perusahaan jasa maupun perusahaan manufaktur.

Menurut Sutrisno dalam bukunya yang berjudul Manajemen Keuangan Teori Konsep dan Aplikasi (2013:89) menjelaskan bahwa 
persediaan adalah "Sejumlah barang atau bahan yang dimiliki oleh perusahaan yang tujuannya untuk dijual dan atau diolah kembali.

Perputaran Persediaan

Menurut Kasmir (2015:114) dalam bukunya yang berjudul pengantar manajemen keuangan menjelaskan bahwa perputaran persediaan (inventory turnover), Merupakan rasio yang digunakan untuk mengukur berapa kali dana yang ditanam dalam sediaan (inventory) ini berputar dalam suatu periode.

2.5 Return On Investment (ROI)

Menurut kasmir dalam bukunya yang berjudul Analisis Laporan Keuangan (2015:201) hasil pengembalian investasi atau lebih dikenal dengan nama Return On Investment (ROI) atau return on total assets merupakan rasio yang menunjukan hasil (return) atas jumlah aktiva yang digunakan dalam perusahaan. ROI juga merupakan suatu ukuran tentang efektivitas manajemen dalam mengelola investasinya.

Menurut Dwi Prastowo dalam bukunya yang berjudul Analisis Laporan Keuangan (2014:90) Return on Investment merupakan terminologi yang luas dari ratio yang digunakan untuk mengukur hubungan antara laba yang diperoleh dan investasi yang digunakan untuk menghasilkan laba tersebut.

Menurut Sutrisno dalam bukunya yang berjudul Manajemen Keuangan Teori Konsep dan Aplikasi (2013:230) menjelaskan bahwa Return On Investment "Merupakan kemampuan perusahaan untuk menghasilkan keuntungan yang akan digunakan untuk mengukur rasio ini adalah laba bersih setelah pajak atau EAT".

Rasio ini dikenal dengan nama rasio perputaran sediaan. Dapat diartikan pula bahwa perputaran sediaan merupakan rasio yang menunjukkan berapa kali jumlah barang sediaan diganti dalam satu tahu. Makin kecil rasio ini, maka makin jelek demikian pula sebaliknya.

\section{Pembahasan}

\section{Hasil Penelitian}

Kondisi Perputaran Piutang dan Perputaran Persediaan terhadap ROI Pada PT. Alam Sutera Reality Tbk, PT. Bekasi Asri Pemula Tbk, dan PT. Bumi Citra Permai Tbk.

1. Perputaran Piutang rasio yang digunakan untuk mengukur berapa lama penagihan piutang selama satu periode (Muhlis, 
Soepeno, \& Rachmatulaily, 2018).

Receivable Turnover $=\frac{\text { Penjualan Kredit }}{\text { Rata-rata Piutang }}$

2. Perputaran Persediaan

yang tujuannya untuk dijual dan atau diolah kembali

Sejumlah barang atau bahan

yang dimiliki oleh perusahaan

Perputaran Persediaan $=\frac{\text { Harga Pokok Penjualan }}{\text { Rata }- \text { Rata Persediaan }}$

3. Return On Invesment

Merupakan

perusahaan

kemampuan

untuk

mengukur rasio ini adalah laba bersih setelah pajak atau EAT menghasilkan keuntungan yang akan digunakan untuk

Return On Investment $(\mathrm{ROI})=\frac{\text { Earning After Interest and Tax }}{\text { Total Assets }}$

Hasil Pengaruh Perputaran Piutang pada Return On
Invesment Objek Penelitian

Periode 2010-2017.

Perputaran Piutang

\begin{tabular}{|l|l|l|l|}
\hline \multirow{2}{*}{ Tahun } & \multicolumn{3}{|l|}{ Kode Perusahaan } \\
\cline { 2 - 4 } & ASRI & BAPA & BCIP \\
\hline 2010 & 38,07 & 1,84 & 5,54 \\
\hline 2011 & 62,25 & 0,81 & 4,80 \\
\hline 2012 & 82,38 & 0,65 & 7,43 \\
\hline 2013 & 58,47 & 4,07 & 11,6 \\
\hline
\end{tabular}




\begin{tabular}{|l|l|l|l|}
\hline 2014 & 25,17 & 134,36 & 13,20 \\
\hline 2015 & 16,12 & 0,56 & 10,55 \\
\hline 2016 & 15,41 & 210,31 & 14,07 \\
\hline 2017 & 18,11 & 290,19 & 8,82 \\
\hline
\end{tabular}

Return On Invesment

\begin{tabular}{|l|l|l|l|}
\hline \multirow{2}{*}{ Tahun } & \multicolumn{3}{l|}{ Kode Perusahaan } \\
\cline { 2 - 4 } & ASRI & BAPA & BCIP \\
\hline 2010 & 6,33 & 13,87 & 9,72 \\
\hline 2011 & 10,03 & 3,99 & 1,01 \\
\hline 2012 & 11,11 & 2,82 & 2,78 \\
\hline 2013 & 6,17 & 2,85 & 7,56 \\
\hline 2014 & 6,95 & 4,00 & 5,17 \\
\hline 2015 & 3,67 & 1,28 & 0,65 \\
\hline 2016 & 2,58 & 1,003 & 6,31 \\
\hline 2017 & 6,68 & 7,22 & 6,50 \\
\hline
\end{tabular}

Model Summaryb

\begin{tabular}{|c|c|c|c|c|}
\hline Model & $\mathrm{R}$ & $\begin{array}{c}\mathrm{R} \\
\text { Square }\end{array}$ & $\begin{array}{l}\text { Adjusted } \\
\text { R Square }\end{array}$ & Std. Error of the Estimate \\
\hline 1 &, $036^{a}$ & ,001 &,- 044 & 3,519 \\
\hline
\end{tabular}

a. Predictors: (Constant), Perputaran Piutang

b. Dependent Variable: ROI

1. Analisis Koefisien Korelasi

Yang mana dari hasil SPSS 24 pada tabel 16 ini menunjukkan nilai Korelasi (R) sebesar 0,036 artinya terjadi hubungan yang sangat rendah dan negatif antara Perputaran Piutang dan Return On Invesment. Karena berada di bawah 0,5. Semakin rendahnya pada nilai $\mathrm{R}$ maka semakin lemah hubungannya tersebut.
2. Analisis

Koefisien

Determinasi

Yang mana dari hasil SPSS 24 pada tabel 16 ini menunjukkan nilai Koefisien determinasi ( $\left.R_{\text {square }}\right)$ sebesar 0,001 atau $0,1 \%$ adalah penguadratan dari R, artinya Return On Invesment dipengaruhi sebesar 0,1 \% oleh Perputaran Piutang sedangkan sisanya di 


\section{Coefficients $^{\mathrm{a}}$}

\begin{tabular}{|c|c|c|c|c|c|c|}
\hline \multirow{2}{*}{\multicolumn{2}{|c|}{ Model }} & \multicolumn{2}{|c|}{$\begin{array}{c}\text { Unstandardized } \\
\text { Coefficients }\end{array}$} & \multirow{2}{*}{$\begin{array}{c}\text { Standardized } \\
\text { Coefficients } \\
\text { Beta } \\
\end{array}$} & \multirow[t]{2}{*}{$\mathbf{T}$} & \multirow[t]{2}{*}{$\begin{array}{l}\text { Si } \\
\text { g. }\end{array}$} \\
\hline & & $\mathrm{B}$ & Std. Error & & & \\
\hline \multirow[t]{3}{*}{1} & (Consta & 5,321 & ,842 & & 6,3 & , 0 \\
\hline & nt) & & & & 22 & $\begin{array}{l}0 \\
0\end{array}$ \\
\hline & $\begin{array}{l}\text { Perputa } \\
\text { ran } \\
\text { Piutang }\end{array}$ & ,002 & ,010 & ,036 & $\begin{array}{r}17 \\
0\end{array}$ & $\begin{array}{l}8 \\
6 \\
7\end{array}$ \\
\hline
\end{tabular}

a. Dependent Variable: ROI

Berdasarkan uji coefficients pada tabel 17 diatas, yang mana diketahui persamaan regresi yang diperoleh $Y=5,321+0,002 \mathrm{X}$, yang menyatakan adanya peningkatan atau penurunan $X_{1}$ (Perputaran Piutang) pada Y (Return On Invesment).

\section{Uji Hipotesis (Probabilitas} 0,05 )

Yang mana pada uji probabilitas $(0,05)$, adanya perolehan pada nilai signifikan sebesar 0,867 kemudian dibandingkan dengan nilai probabilitasnya 0,05 , ternyata nilai signifikan sebesar 0,867 > 0,05 sedangkan pada nilai t hitung $0,170<2,074 \mathrm{t}$ tabel, artinya
Perputaran Piutang tidak berpengaruh secara tidak signifikan maka $H_{a}$ Ditolak dan $H_{o}$ Diterima.

Hasil Pengaruh Perputaran Persediaan pada Return On Invesment Objek Penelitian Periode 2010-2017.

Perhitungan ini digunakan adanya pencarian seberapa besar dan signifikannya pengaruh perputaran persediaan terhadap return on invesment yang menjadi objek penelitin dalam perusahaan properti ini dengan periode tahun 2010-2017.

Perputaran Persediaan

\begin{tabular}{|l|l|l|l|}
\hline \multirow{2}{*}{ Tahun } & \multicolumn{3}{|l|}{ Kode Perusahaan } \\
\cline { 2 - 4 } & ASRI & BAPA & BCIP \\
\hline 2010 & 173,31 & 1,05 & 0,60 \\
\hline 2011 & 247,38 & 0,17 & 0,35 \\
\hline 2012 & 0,72 & 0,11 & 0,75 \\
\hline
\end{tabular}




\begin{tabular}{|l|l|l|l|}
\hline 2013 & 1,42 & 0,14 & 1,16 \\
\hline 2014 & 1,42 & 0,15 & 1,35 \\
\hline 2015 & 0,70 & 0,18 & 0,61 \\
\hline 2016 & 1,06 & 0,8 & 0,71 \\
\hline 2017 & 1,42 & 0,12 & 0,58 \\
\hline
\end{tabular}

Return On Invesment

\begin{tabular}{|l|l|l|l|}
\hline \multirow{2}{*}{ Tahun } & \multicolumn{3}{l|}{ Kode Perusahaan } \\
\cline { 2 - 4 } & ASRI & BAPA & BCIP \\
\hline 2010 & 6,33 & 13,87 & 9,72 \\
\hline 2011 & 10,03 & 3,99 & 1,01 \\
\hline 2012 & 11,11 & 2,82 & 2,78 \\
\hline 2013 & 6,17 & 2,85 & 7,56 \\
\hline 2014 & 6,95 & 4,00 & 5,17 \\
\hline 2015 & 3,67 & 1,28 & 0,65 \\
\hline 2016 & 2,58 & 1,003 & 6,31 \\
\hline 2017 & 6,68 & 7,22 & 6,50 \\
\hline
\end{tabular}

Model Summary ${ }^{b}$

\begin{tabular}{|l|r|r|c|c|}
\hline $\begin{array}{l}\text { Mode } \\
\mathrm{l}\end{array}$ & $\mathrm{R}$ & $\begin{array}{c}\mathrm{R} \\
\text { Square }\end{array}$ & $\begin{array}{c}\text { Adjusted } \mathrm{R} \\
\text { Square }\end{array}$ & $\begin{array}{c}\text { Std. Error of the } \\
\text { Estimate }\end{array}$ \\
\hline 1 &, $274^{\mathrm{a}}$ &, 075 &, 033 & 3,388 \\
\hline
\end{tabular}

a. Predictors: (Constant), Perputaran Persediaan

b. Dependent Variable: ROI

1. Analisis Koefisien Korelasi

Yang mana dari hasil SPSS 24 pada tabel 19 ini menunjukkan nilai Korelasi (R) sebesar 0,274 artinya terjadi hubungan yang rendah dan negatif antara Perputaran Persediaan dan Return On Invesment. Karena berada di bawah 0,5. Semakin rendahnya pada nilai $\mathrm{R}$ maka semakin lemah hubungannya tersebut.

2. Analisis Koefisien Determinasi
Yang mana dari hasil SPSS 24 pada tabel 19 ini menunjukkan nilai Koefisien determinasi ( $\left.R_{\text {square }}\right)$ sebesar 0,075 atau 7,5\% adalah penguadratan dari $\mathrm{R}$, artinya Return On Invesment dipengaruhi sebesar 7,5 \% oleh Perputaran Persediaan sedangkan sisanya 92,5\% di pengaruhi oleh suatu sebab yang tidak dibahas oleh peneliti. 


\begin{tabular}{|c|c|c|c|c|c|c|}
\hline \multirow{2}{*}{\multicolumn{2}{|c|}{ Model }} & \multicolumn{2}{|c|}{$\begin{array}{l}\text { Unstandardi } \\
\text { zed } \\
\text { Coefficients }\end{array}$} & \multirow{2}{*}{$\begin{array}{c}\text { Standard } \\
\text { ized } \\
\text { Coefficie } \\
\text { nts } \\
\text { Beta }\end{array}$} & \multirow[t]{2}{*}{$\mathrm{T}$} & \multirow[t]{2}{*}{ Sig. } \\
\hline & & B & $\begin{array}{c}\text { Std. } \\
\text { Error }\end{array}$ & & & \\
\hline \multirow[t]{2}{*}{1} & $\begin{array}{l}\text { (Const } \\
\text { ant) }\end{array}$ & $\begin{array}{r}5,1 \\
43\end{array}$ & ,724 & & $\begin{array}{r}7,10 \\
6\end{array}$ & ,000 \\
\hline & $\begin{array}{l}\text { Perput } \\
\text { aran } \\
\text { Persed } \\
\text { iaan }\end{array}$ & $\begin{array}{r}, 01 \\
6\end{array}$ & 012 & ,274 & $\begin{array}{r}1,33 \\
5\end{array}$ & 195 \\
\hline
\end{tabular}

a. Dependent Variable: ROI

Berdasarkan uji coefficients pada tabel 20 diatas, yang mana diketahui persamaan regresi yang diperoleh $Y=5,143+0,016 \mathrm{X}$, yang menyatakan adanya peningkatan atau penurunan $X_{2}$ (Perputaran Persediaan) pada Y (Return On Invesment).

3. Uji Hipotesis (Probabilitas 0,05) Yang mana pada uji probabilitas $(0,05)$, adanya perolehan pada nilai signifikan sebesar 0,195 kemudian dibandingkan dengan nilai probabilitasnya 0,05 , ternyata nilai signifikan sebesar 0,195 > 0,05 sedangkan pada nilai thitung 1,335 < 2,074 t tabel, artinya Perputaran Persediaan tidak berpengaruh secara tidak signifikan maka $H_{a}$ Ditolak dan $H_{o}$ Diterima

A.Hasil Pengaruh Perputaran Piutang Dan Perputaran Persediaan pada Return On Invesment Objek Penelitian Periode 2010-2017.

Perhitungan ini digunakan adanya pencarian seberapa besar dan signifikannya pengaruh perputaran piutang dan perputaran persediaan terhadap return on invesment secara simultan, yang menjadi objek penelitin dalam perusahaan properti ini dengan periode tahun 2010-2017.

Model Summaryb

\begin{tabular}{|l|r|r|r|r|}
\hline Model & $\mathrm{R}$ & $\begin{array}{c}\mathrm{R} \\
\text { Square }\end{array}$ & $\begin{array}{c}\text { Adjusted R } \\
\text { Square }\end{array}$ & $\begin{array}{c}\text { Std. Error of the } \\
\text { Estimate }\end{array}$ \\
\hline 1 &, $275^{\mathrm{a}}$ &, 076 &,- 012 & 3,466 \\
\hline
\end{tabular}


a. Predictors: (Constant), Perputaran Persediaan, Perputaran Piutang

b. Dependent Variable: ROI

1. Analisis Koefisien Korelasi

Yang mana dari hasil SPSS 24 pada tabel 21 ini menunjukkan nilai Korelasi (R) sebesar 0,275 atau $27,5 \%$, artinya terjadi hubungan yang rendah dan negatif antara Perputaran Piutang dan Perputaran Persediaan dan Return On Invesment. Karena berada di bawah 0,5. Semakin rendahnya pada nilai $\mathrm{R}$ maka semakin lemah hubungannya tersebut.

\section{Analisis Koefisien Determinasi}

Yang mana dari hasil SPSS 24 pada tabel 21 ini menunjukkan nilai
Koefisien determinasi ( $\left.R_{\text {square }}\right)$ sebesar 0,076 atau 7,6\% adalah penguadratan dari R, artinya Return On Invesment dipengaruhi sebesar 7,6 \% oleh Perputaran Piutang dan Perputaran Persediaan sedangkan sisanya $92,4 \%$ di pengaruhi oleh suatu sebab yang tidak dibahas oleh peneliti.

\section{ANOVA $^{a}$}

\begin{tabular}{|l|l|r|r|r|r|r|}
\hline \multicolumn{2}{|l|}{ Model } & $\begin{array}{c}\text { Sum } \\
\text { of } \\
\text { Squar } \\
\text { es }\end{array}$ & df & $\begin{array}{c}\text { Mean } \\
\text { Square }\end{array}$ & F & Sig. \\
\hline 1 & Regres & 20,63 & 2 & 10,318 &, 858 &, $438^{\text {b }}$ \\
& sion & 5 & & & & \\
\cline { 2 - 7 } & Residu & 252,4 & 2 & 12,020 & & \\
& al & 18 & 1 & & & \\
\cline { 2 - 8 } & Total & 273,0 & 2 & & & \\
& & 54 & 3 & & & \\
\hline
\end{tabular}

a. Dependent Variable: ROI

b. Predictors: (Constant), Perputaran Persediaan, Perputaran Piutang

Berdasarkan hasil uji ANOVA pada tabel 22 diatas, adanya perolehan

nilai $F$ sebesar 0,858 dengan signifikannya 0,438 .

\section{Coefficients $^{\mathbf{a}}$}

\begin{tabular}{|l|c|c|c|c|}
\hline Model & $\begin{array}{c}\text { Unstandardi } \\
\text { zed } \\
\text { Coefficients }\end{array}$ & $\begin{array}{c}\text { Standardized } \\
\text { Coefficients }\end{array}$ & $\mathrm{T}$ & Sig. \\
\hline
\end{tabular}




\begin{tabular}{|l|l|r|r|r|r|r|}
\hline \multicolumn{2}{|c|}{} & \multicolumn{1}{|c|}{ B } & $\begin{array}{c}\text { Std. } \\
\text { Error }\end{array}$ & Beta & & \\
\hline 1 & $\begin{array}{l}\text { Consta } \\
\text { nt) }\end{array}$ & 5,0 &, 853 & & 5,969 &, 000 \\
\cline { 2 - 7 } & $\begin{array}{l}\text { Perput } \\
\text { aran }\end{array}$ &, 00 &, 010 &, 024 &, 115 &, 909 \\
& Piutang & 1 & & & & \\
\cline { 2 - 7 } & $\begin{array}{l}\text { Perput } \\
\text { aran } \\
\text { Persedi } \\
\text { aan }\end{array}$ &, 01 &, 012 &, 273 & 1,300 &, 208 \\
\hline
\end{tabular}

a. Dependent Variable: ROI

Berdasarkan uji coefficients pada tabel 22 diatas, yang mana diketahui persamaan regresi yang diperoleh $Y=5,094+0,001 X_{1}+0,016 X_{2}$, dari persamaan tersebut yang menyatakan persamaan nilai konstantanya 5,094 jika $X_{1}$ dan $X_{2}$ bernilai nol maka diperkirakan nilai ROI adalah Rp 5,094.

3. Uji Hipotesis (Probabilitas 0,05)

Yang mana pada uji probabilitas $(0,05)$, adanya perolehan pada nilai signifikan sebesar 0,438 atau $43,8 \%$ artinya nilai ini sangat signifikan di tingkat $5 \%(0,05)$ kemudian dibandingkan dengan nilai probabilitasnya 0,05 , ternyata nilai signifikan sebesar $0,438>0,05$ sedangkan pada nilai f hitung $0,858<3,47 \mathrm{ftabel}$, sehingga $H_{a}$ Ditolak dan $H_{o}$ diterima. Dengan ini maka Perputaran Piutang $X_{1}$, Perputaran Persediaan $X_{2}$ tidak berpengaruh secara tidak signifikan terhadap Return On Invesment.

\section{Kesimpulan Dan Saran}

\section{Kesimpulan}

1. Berdasarkan analisis data dan yang telah di teliti pada bagian ini maka disimpulkan diperoleh hasil bahwa Perputaran Piutang tidak berpengaruh terhadap Return On Invesment (ROI) dapat dilihat dari perolehan nilai pada $\mathrm{t}$ hitung $0,170<2,074 \mathrm{t}$ tabel, yang mana tingkat signifikannya pada Perputaran Piutang sebesar 0,867 > 0,05 berarti tidak berpengaruh secara signifikan.

2. Berdasarkan analisis data dan yang telah di teliti pada bagian ini maka disimpulkan diperoleh hasil bahwa Perputaran Persediaan tidak berpengaruh terhadap Return On Invesment (ROI) dapat dilihat dari perolehan nilai pada $\mathrm{t}$ hitung $1,335<2,074 \mathrm{t}$ tabel, yang mana tingkat signifikannya pada Perputaran Persediaan sebesar 0,195 $>0,05$ berarti tidak berpengaruh secara signifikan. 
3. Berdasarkan analisis data yang simultan dan yang telah di teliti pada bagian maka disimpulkan diperoleh hasil bahwa Perputaran Piutang dan Perputaran Persediaan tidak berpengaruh terhadap Return On Invesment (ROI) dapat dilihat dari perolehan nilai pada f hitung $0,858<3,47 \mathrm{ftabel}$, tidak signifikan di tingkat 5\% $(0,05)$. Maka $H_{a}$ Ditolak dan $H_{o}$ diterima.

\section{Saran}

1. Bagi Pihak Perusahaan

Sebaiknya perusahaan terus memperhatikan tentang adanya tingkat persediaan yang cukup untuk perkembangan terhadap suatu penjualan yang akan di proses nantinya dan bisa untuk adanya penjualan tersebut diperhatikan dengan proses pada piutang (Tagihan/Kredit), dan bagaimana pentingnya perusahaan mengelola pada tahap penjualan secara piutang karena ketika piutang pun lancar maka akan berdampak baik juga untuk kebutuhan persediaan dan tingkat penghasilan perusahaan pun supaya berdampak laba meningkat dengan baik.

2. Bagi Pihak Investor

Sebaiknya bagi para investor untuk yang akan ingin berinvestasi atau menanamkan modal juga ingin membeli suatu saham pada perusahaan, terus update perkembangan dan kemajuan suatu perusahaan yang akan dipilih supaya ketika berinvestasi terus mendapatkan keuntungan ketika memastikan tersebut.

\section{Daftar Pustaka}

Agus S. (2015). Manajemen Keuangan Teori dan Aplikasi. Yogyakarta: BPFEYogyakarta.

Kasmir. (2015). Analisis Laporan Keuangan. Jakarta: Rajagrafindo Persada.

Muhlis, M., Soepeno, \& Rachmatulaily. (2018). Pelatihan dan Pemotivasian

Terhadap Pengembangan Karir Karyawan. Manager : Jurnal Ilmu

Manajemen, 1(1), 45-56. 